\title{
PROGRAM WISATA BERSIH MELALUI PEMBERIAN REWARD DALAM MENINGKATKAN DAYA TARIK WISATAWAN DI BANYUWANGI
}

\author{
Nadiya Lifa Ningrum ${ }^{1}$, Saiful Rohman ${ }^{2}$ \\ Akademi Kelautan Banyuwangi; Banyuwangi, 087859155606 \\ Email: nadiyalifaningrum@gmail.com
}

\begin{abstract}
Tourism is the leading sector in Banyuwangi, but the increasing number of tourists who is visiting Banyuwangi will causes more and more volumes of waste. Bangsring Underwater is a top destination Banyuwangi that is Frequently visited by tourists. The purpose of this study is to find outthe solutionswhich related to waste problems in order to Minimized the impact and supporting factors and obstacles in the implementation of waste management programs in Bangsring Underwater tourism.The method in this study was qualitative method. The result of this study is lean tourism programs that Is realized by the movement for not leaving garbage on tourism place. This program is carried out by providing garbage bags from totebags as trash that cangenerated from every tourist activity during their visit. Garbage in the totebag is obtained from the packaging of food and beverage waste carried by tourists when traveling and garbage around them. When tourists left,. The totebag which is containing garbage must be returned to manager at the exit door. If they do that kind of thing, they will be rewarded This is an advantage in the program carried out by researchers. Reward in the clean travel program is an award for who has been following the rules which determined by tourism manager. The supporting factors in this program are come form management of bangsring underwater banyuwangi also departement of culture and tourism and the banyuwangi environment agency. While the inhibition is on formation of a hygiene monitoring team in Bangsring Underwater.
\end{abstract}

Keywords: Clean tourism,reward, waste management, tourism

\section{Pendahuluan}

Pariwisata merupakan salah satu aset pendorong bagi suatu daerah untuk menjadi daerah maju.Industri pariwisata juga merupakan sumber devisa dan pendapatan untuk perusahaan dan pemerintah yang menjual jasa kepada wisatawan. Pengembangan industri pariwisata merupakan strategi yang dipakai oleh organisasi pemerintah dan NonPemerintah untuk mempromosikan wilayah tertentu sebagai daerah wisata untuk meningkatkan perdagangan melalui penjualan jasa kepada wisatawan. Salah satu daerah yang memiliki objek wisata yang sangat beragam adalah Kabupaten Banyuwangi. Objek wisata tersebut di antaranya objek wisata alam, budaya, dan sejarah. Banyuwangi merupakan salah satu kabupaten yang berada di provinsi Jawa Timur. Banyuwangi juga 
salah satu kabupaten penyumbang sektor pariwisata yang cukup besar bagi Jawa Timur khususnya di bidang pariwisata bahari dimana pariwisata tersebut berpotensi mengundang wisatawan lokal maupun manca negara. Pariwisata Banyuwangi juga diharapkan mampu memperkuat daerah sebagai sentra ekonomi baru di kawasan timur pulau Jawa. Adapun jumlah kunjungan wisatawan domestik sejak tahun 2013 hingga tahun 2019 mengalami peningkatan yang signifikan atau tergolong tinggi. Hal ini dibuktikan pada tahun 2013 wisatawan domestik yang mengunjungi Kabupaten Banyuwangi sejumlah 1.057 .952 orang atau wisatawan dan di tahun 2019 jumlah wisatawan domestik yang mengunjungi Kabupaten Banyuwangi menjadi 5.307.054 orang atau wisatawan. Selain itu, peningkatan wisatawan mancanegara juga mengalami peningkatan. Hal ini di buktikan dari jumlah kunjungan wisatawan mancanegara di Kabupaten Banyuwangi pada tahun 2013 sebanyak 10.462 orang, meningkat signifikan menjadi 101.622 orang di tahun 2019. Keberhasilan tersebut tentu tidak terlepas dari perhatian pemerintah terhadap sektor pariwisata tersebut. Selain meningkatkan fasilitas yang terdapat pada destinasi wisata, pemerintah daerah juga giat mengadakan kegiatan di tempat wisata (Event Tourism) bersekala nasional hingga internasional (Badan Pusat Statistik).

Melihat peningkatan yang signifikan wisatawan dosmetik dengan total 5,4 jt wisatawan di tahun 2019, Bangsring Underwater merupakan salah satu destinasi yang ikut meningkat jumlah kunjungan atau wisatawannya. Hal ini senada dengan pernyataan Dinas Kebudayaan dan Pariwisata Banyuwangi yang mencatat 5,4 juta wisatawan yang berkunjung di Banyuwangi tahun 2019 berkunjung di beberapa tempat favorit di antaranya Gunung Ijen, pulau Merah, Grand New Watu Dodol, Djawatan, Bangsring Underwater dan Pantai Cacalan ( https://mediaindonesia.com). Peningkatan jumlah wisatawan setiap tahunnya terjadi pada setiap hari weekend maupun hari libur besar. Wisatawan yang datang ke wisata ini berasal dari dalam negeri maupun luar negeri. banyaknya wisatawan yang berkunjung ke pantai Bangsring ini karena daya tarik bawah laut pantai bangsring yang begitu indah untuk snorkeling dan diving, selain itu penangkaran hiu dan rumah apung juga menjadi daya tarik tersendiri untuk wisatawatan berkunjung ke Bangsring underwater. Hal ini menunjukkan bahwa objek wisata ini semakin dikenal oleh masyarakat dan mengalami perubahan yang lebih baik.

Namun demikian dengan meningkatnya jumlah wisatawan yang berkunjung ke Bangsring underwater menyebabkan timbulnya permasalahan baru terkait sampah yang menumpuk dipermukaan laut pantai Bangsring. Hal ini juga dikatakan oleh Menteri Kelautan saat berkunjung ke Bangsring Underwater pada bulan april tahun 2019 yakni masih banyak sampah-sampah yang mengambang di permukaan laut ketika dirinya memberikan makan ikan(https://www.suara.com). Banyaknya sampah yang ada di permukaan pantai Bangsring dan sekitarnya merupakan akibat kesalahan wisatawan yang masih belum tertib untuk membuang sampah pada tempatnya dan masih sering menggunakan plastik sekali pakai. Hal ini yang menjadi perhatian apabila permasalahan sampah dibiarkan akan merusak lingkungan Bangsring Underwater dan ekosistem yang ada didalam laut Bangsring. Berdasarkan hal tersebut maka tujuan dari penelitian ini untuk mengetahui bagaimana solusi terkait masalah sampah dapat diminimalisir oleh wisatawan ketika berkunjung di Bangsring Underwater dan factor pendukung serta penghambat dalam pelaksanaan program pengelolaan sampah di wisata Bangsring Underwater.

\section{Landasan Teori}

\section{Pariwisata}

Menurut Undang-Undamg Republik Indonesia no 10 tahun 2009 Pariwisata merupakan suatu kegiatan perjalanan yang dilakukan manusia baik perorangan maupun kelompok untuk mengunjungi destinasi tertentu dengan tujuan rekreasi, mempelajari 
keunikan daerah pariwisata, pengembangan diri dan sebagainya dalam kurun waktu yang singkat atau sementara waktu. Pariwisata juga merupakan kegiatan manusia yang melakukan perjalanan dengan tujuan mendapatkan kenikmatan, mencari kepuasan, mengetahui sesuatu, memperbaiki kesehatan, menikmati olahraga atau istirahat, menunaikan tugas, berziarah dan lain-lain(Menurut James J. Spillane :1982). Dari pengertian para ahli tersebut dapat disimpulkan bahwa pariwisata merupakan sebuah kebutuhan jiwa dan raga seseorang untuk melakukan sebuah perjalanan dalam waktu yang sementara ketempat atau destinasi yang menurutnya memiliki nilai keindahan untuk pemenuhan kebutuhan dirinya.

\section{Daya Tarik Wisata}

Aspek yang mendasar dalam keberhasilan mewujudkan daya tarik wisata dalam pembangunan kepariwisataan yakni dengan menciptakan lingkungan dan suasana kondusif yang dapat mendorong tumbuh dan berkembangnya kegiatan kepariwisataan disuatu tempat wisata. Lingkungan kondusif dapat diwujudkan dengan adanya perwujudan sadar wisata dan sapta pesona yang dikembangkan secara konsisten oleh masyarakat sekitar destinasi wisata. Sadar wisata diwujudkan sebagai bentuk kesadaran masyarakat sekitar untuk berperan aktif dalam menyadari peran dan tanggung jawab sebagai tuan rumah yang baik namun menyadari ha dan kebutuhannya untuk menjadi pelaku wisata disuatu tujuan wisata. Sedangkan sapta pesona merupakan tujuh unsure peson yang harus diwujudkan bagi terciptanya lingkungan yang kondusif bagi berkembangnya kegiatan kepariwisataan disuatu tempat yang mendorong untuk menjadikan daya tarik bagi wisatawan. Adapun tujuh sapta pesona yakni sebagai berikut:

1) Aman yakni Kondisi lingkungan disuatu destinasi pariwisata yng memberikan rasa tenang, bebas dari rasa takut dan kecemasan bagi wisatawan dalam melakukan perjalanan atau berwisata ke destinasi tersebut. Selain itu keamanan juga berarti menjaga atau menjamin keselamatan jiwa dan fisik wisatawan dan menjaga barang milik wisatawan.

2) Tertib yakni Suatu destinasi wisata juga harus memiliki kondisi yang tertib yakni kondisi atau suasana yang teratur, rapi, dan lancar serta dapat memberikan layanan yang disiplin tinggi sehingga destinasi tersebut sangat didambakan oleh setiap orang atau wisatawan.

3) Bersih merupakan Setiap destinasi wisata harus dapat menunjukkan kebersihan lingkungannya karena hal itu merupakan kualitas produk dan pelayanan di dalam destinasi wisata. Selain itu bersih mrupakan suatu kondisi yang menampilkan suasana bebas dari sampah, limbah, kotoran, penyakit dan pencemaran. Dengan menjaga kebersihan tempat wisata akan menjadikan wisatawan merasa nyaman dan betah ketika berwisata.

4) Sejuk yaitu Suasana sejuk di dalam destinasi wisata mencerminkan keadaan yang dapat memberikan perasan nyaman bagi wisatawan ketika berwisata di daerah tersebut. Indah merupakan Suatu destiasi wisata yang mencerminkan keadaan yang indah dan menarik akan dapat memberikan rasa kagum dan memberikan kesan"interest" bagi wisatawan dalam melakukan perjalanan ke destinasi tersebut. Adanya kesan indah dari wisatawan ini dapa mewujudkan potensi kunjungan ulang dan mendorong promosi melalui kesan wisatawan.

5) Ramah

Pegelola destinasi wisata harus dapat menampilkan sikap yang ramah kepada para wisatawan yang sedang berwisata, hal ini dapat mencerminkan suasana yang akrab, terbuka, dan penerimaan yang baik akan memberikan perasaan nyaman dibenak wisatawan, perasaan diterima dan "betah" bagi wisatawan ketika berwisata.

6) Kenangan yakni Suatu destinasi juga harus dapat memberikan pengalaman yang berkesan untuk wisatawan. Pengalaman yang berkesan tercermin denan adanya rasa 
senang dan kenangan indah yang membekas bagi wisatawan ketika berwisata. Reward

Menurut Sutrisno (2009:197) berpendapat bahwa atau penghargaan merupakan bentuk balas jasa yang diberikan perusahaan kepada karyawan atas dasar pengorbanan waktu, tenaga, dan pikiran. Dalam penelitian ini reward yang dimaksud yakni dalam pemberian penghargaan sebagai balas jasa kepada wisatawan yang sudah bersedia meluangkan waktu dn tenaganya untuk mengumpulkan sampah pada setiap akifitasnya di tempat wisata. Adapun tujuan pemberian reward salah satunya yakni menarik (Attract) yakni Reward harus mampu menarik orang yang berkualitas untuk menjadi anggota organisasi, sehingga dalam penelitian ini tujuan dari pemberian reward yakni untuk menjadi daya tarik wisatawan untuk berkunjung ke tempat wisata.

\section{Metode Penelitian \\ Jenis Penelitian}

Metode penelitian bukan sekedar alat, tetapi juga sebagai prosedur, teknik, desain, dan tata cara untuk memandu peneliti tentang bagaimana penelitian dilakukan agar dapat memperoleh data yang dikehendaki sesuai dengan permasalahan yang akan diteliti. Dalam penelitian ini, jenis penelitian yang digunakan adalah kualitatif naratif atau deskripsi yakni metode yang bertujuan untuk mengeksplorasi dan memahami makna oleh sejumlah individu atau kelompok orang yang dianggap berasal dari masalah social atau kemanusiaan (Creswel,2013:4-5). Pengumpulan data dilakukan dengan wawancara mendalam dan observasi kepada partisipan. Berdasarkan hal tersebut, penelitian berupaya untuk mendeskripsikan, menguraikan, permasalahan serta kemudian mengambil kesimpulan dari masalah serta mencari solusi tentang penggunakan tas sampah sebagai usaha mengurangi sampah pesisir pantai Bangsring Underwater

\section{Fokus Penelitian}

Menetapkan fokus berdasarkan permasalahan yang terkait dengan teori yang telah ada penentuan fokus lebih diarahkan pada tingkat kebaruan informasi yang akan diperoleh dari situasi sosial (lapangan) dan juga menghindari peneliti dari pengumpulan data yang tidak perlu maka penelitian ini perlu difokuskan sesuai dengan rumusan masalah yang telah ditentukan dalam penelitian ini.

Dalam penelitian ini, peneliti telah menentukan fokus penelitian yakni :

1. Penerapan program tas sampah untuk menanggulangi sampah pesisir pantai di Bangsring Underwater

2. Faktor pendorong program tas sampah untuk menanggulangi sampah pesisir pantai di Bangsring Underwater

\section{Instrumen Penelitian}

Instrumen utama pengumpulan data pada sebuah penelitian kualitatif adalah peneliti itu sendiri atau apa yang disebut sebagai human instrument (Bungin, 2001:71 dan Danim, 2002: 135). Dalam penelitian ini terdapat beberapa instrumen yang akan dipakai peneliti, diantaranya:

1. Interview / Wawancara

Wawancara. Kegiatan wawancara dilakukan terhadap narasumber yang dianggap kompeten dalam suatu hal. Metode yang digunakan merupakan wawancara terbuka dimana urutan pertanyaan bersifat acak tergantung dari kesiapan narasumber. Sejumlah hal yang ditanyakan dalam wawancara yaitu pertanyaan berkaitan dengan pengalaman, pertanyaan berkaitan dengan pendapat, pertanyaan yang berkaitan dengan informasi. Dalam hal ini yang menjadi narasumber dalam kegiatan wawancara adalah informan A selaku salah satu pihak pengelola wisata Bangsring Underwater Banyuwangi. 
2. Observasi

Objek observasi yang digunakan yaitu Bangsring Underwater Banyuwangi yakni interaksi sedang berlangsung/akan berlangsung, identifikasi pelaku atau orang yang sedang memainkan peran tertentu, serta observasi kegiatan yang sedang dilakukan oleh aktor / pihak terkait. Secara umum materi observasi yang dilakukan mencakup hal yaitu, observasi terkait pengelolaan sampah dan limbah wisatawan yang telah dilakukan.

3. PenyimpulanData dan Dokumentasi

Pengumpulan data diperlukan untuk melihat perkembangan pada pengelolaan sampah dan limbah yang ada di pesisir pantai serta adanya dokumentasi dilakukan dalam rangka memperoleh data fisik secara langsung kondisi dilapangan sehingga kita bisa mengambil keputusan yang tepat apakah strategi yang akan kita gunakan efektif sebagai usaha mengelola sampah khususnya destinasi wisata daerah Bangsring Underwater Banyuwangi.

\section{Pengumpulan Data dan Pengolahan Data}

Data dalam penelitian ini terdiri dari dua yaitu primer dan sekunder:

a. Menurut Indriantoro dan Supomo (2002:147) "Data primer merupakan sumber data penelitian yang diperoleh langsung dari sumber asli (tidak melalui media perantara). Data primer secara khusus dikumpulkan oleh peneliti untuk menjawab pertanyaan penelitian. Data primer dalam penelitian diperoleh dari wawancara dengan informan kunci yakni ketua pengelola Bangsring Underwater, anggota pengelola Bangsring Underwater, serta dengan dinas kebudayaan dan pariwisata Banyuwangi, selain itu peneliti juga observasi langsung di Bangsring Underwater.

b. Data sekunder, yaitu data yang diperoleh secara tidak langsung. Data ini diperoleh dari studi kepustakaan, yaitu metode pengumpulan data dengan melihat beberapa literatur, antara lain catatan, buku, hubungannya dengan penelitian tersebut. Menurut Indriantoro dan Supomo (2002:147) "Data sekunder merupakan sumber data penelitian yang diperoleh peneliti secara tidak langsung melalui media perantara (diperoleh dan dicatat oleh pihak lain).Data sekunder dalam penelitian ini yakni dari data kunjungan wisatawan di Bangsring underwater, buku-buku kepustakaan yang ada kaitannya dengan teori yang dipakai dalam penelitian, serta media online.

\section{Uji Keabsahan Data}

Dalam penelitian ini peneliti menggunakan teknik pemeriksaan keabsahan data yakni metode triangulasi. Winston dalam Bungin (2010:83) mengatakan, "studi kasus merupakan penelitian yang bersifat triangulasi". Triangulasi adalah sebuah teknik yang bertujuan untuk memeriksa keabsahan dengan memanfaatkan sesuatu yang lain. Penelitian ini, menggunakan triangulasi sumber data.

\section{Hasil Penelitian dan Pembahasan Hasil Wawancara}

Berdasarkan wawancara yang telah dilakukan dengan pihak pengelola Bangsring Underwater bahwa setiap tahunnya semakin banyak wisatawan yang datang ke Bangsring Underwater ini namun bertambahnya jumlah wisatawan ini menjadikan lingkungan wisata Bangsring Underwater juga semakin dipenuhi sampah. Hal ini disebabkan karena kurangnya tingkat kesadaran akan kebersihan pantai untuk dijaga bersama. Tingkat kesadaran akan kebersihan tempat wisata bisa dibentuk dengan cara memberikan reward, karena dengan adanya pemberian reward ini wisatawan akan terdorong untuk mengikuti atau melaksanakannya. Hal ini dibuktikan dengan pengalaman yang telah dilakukan oleh pengelola Bangsring Underwater sebelumnya. Pihak pengelola Bangsring Underwater memberikan denda atau hukuman untuk membayar sebesar lima ratus ribu rupiah bagi wisatawan yang membuang sampah sembarangan. Namun hal itu tidak bisa menyadarkan 
kesadaran wisatawan akan pentingnya menjaga kebersihan pantai. Berdasarkan hal ini, pemanfaatan totebag sebagai penyimpanan sampah dengan memberikan apresiasi reward bisa menjadi alternativ untuk meningkatkan kesadaran wisatawan akan pentingnya menjaga lingkungan wisata atau pantai.

Hasil wawancara dengan Dinas Kebudayaan dan Pariwisata Kabupaten Banyuwangi juga mendukung dalam kegiatan berwisata bersih, karena pada dasarnya dalam pariwisata harus mengandung unsur kebersihan yakni yang terkandung dalam panca pesona pariwisata. Unsur kebersihan adalah salah satu unsur yang paling penting dalam produk pariwisata, dengan menjaga kebersihan lingkungan tempat wisata akan dapat memberikan servis atau pelayanan yang menyenangkan dan nyaman untuk para wisatawan sehingga menciptakan "ketertarikan" untuk kembali mengunjungi tempat wisata ini.

Selain itu, adanya dukungan dari pihak pengelola Bangsring Underwater dalam mengarahkan wisatawan menjaga kebersihan lingkungan pantai dengan pemanfaatan totebag akan menjadi factor pendukung atau factor keberhasilan.selain itu adanya dorongan atau dukungan dari dinas kebudayaan dan pariwisata serta dinas lingkungan hidup dalam mengkampanyekan manfaat berwisatawa bersih dengan pemanfaatan totebag ini kepada wisatawan dan masyarakat luas sehingga dapat meningkatkan kesadaran wisatawan dan masyarakat terhadap kebersihan lingkungan pantai. Namun demikian ancaman dari program ini yakni kurangnya pengawasan dari pihak pengelola dalam mengawasi wisatawan, sehingga harus ada pengawasan langsung untuk menjadikan program ini berjalan efektif.

\section{Pembahasan}

\section{Mengurangi sampah di Bangsring Underwater}

Bertambahnya wisatawan yang datang ke Banyuwangi mempengaruhi perkembangan destinasi wisata yang ada di Banyuwangi untuk lebih dikenal oleh masyarakat luas. Namun demikian semakin bertambahnya wisatawan setiap tahunnya juga berdampak pada bertambahnya volume limbah dan sampah yang ada di Banyuwangi khususnya limbah di daerah pesisir pantai karena daerah pesisir merupakan tempat pariwisata dengan potensi tertinggi di Wilayah Banyuwangi. Untuk memastikan terkelolanya sampah di tempat wisata Bangsring underwater dan peningkatan kesadaran masyarakat, dilaksanakan program penelitian feedback kepada masyarakat.

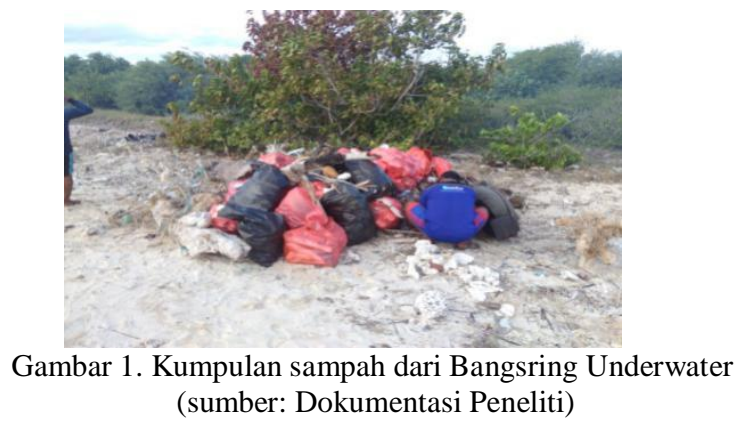

Berdasarkan gambar di atas dapat di lihat banyaknya sampah yang menumpuk di daerah pesisir pantai Bangsring. Sampah ini dihasilkan dari sisa aktivitas wisatawan yang meninggalkan sampah bekas makanan dan minuman. Hal ini menjadikan pentingnya suatu program untuk kegiatan wisata bersih sehingga wisatawan sadar tentang kebersihan lingkungan ketika berwisata di Bangsring Underwater. Program wisata bersih tentunya bertujuan untuk menciptakan tempat wisata pantai yang bersih dari sampah sehingga menjadikan kenyamanan dan kepuasan ketika berwisata. 


\section{Penerapan program berwisata bersih}

Menumpuknya Sampah di permukaan laut dan disekitar wisata Bangsring Underwater menjadikan pentingnya penerapan program berwisata bersih bagi wisatawan yang sedang berkunjung. Hal ini menjadi sangat penting untuk lebih diterapkan bagi pengelola wisata maupun bagi wisatawan, karena sampah ini dihasilkan dari aktivitas wisatawan seperti bungkus makanan/minuman, botol plastik, puntung rokok, kertas dan sisa makanan.Menumpuknya volume sampah ini menunjukkan bahwa semakin banyak jumlah wisatawan yng berkunjung maka semakin tinggi juga volume sampah yang dihasilkan. Hal ini dapat dilihat pada tabel 1 dibawah ini:

\begin{tabular}{|c|c|c|}
\hline No & Bulan & Volume sampah \\
\hline 1 & Januari & 14.116 \\
\hline 2 & Februari & 7.305 \\
\hline 3 & Maret & 4.462 \\
\hline 4 & April & 5.145 \\
\hline 5 & Mei & 2.086 \\
\hline 6 & Juni & 17.418 \\
\hline 7 & Juli & 9.855 \\
\hline 8 & Agustus & 4.760 \\
\hline 9 & September & 4.310 \\
\hline 10 & Oktober & 4.676 \\
\hline 11 & November & 6.058 \\
\hline 12 & Desember & 14.645 \\
\hline
\end{tabular}

Berdasarkan tabel diatas didapatkan volume sampah tertinggi pada bulan Juni tahun 2019, namun demikian bulan januari dan bulan desember juga mencapai volume sampah yang tinggi pula. Hal ini diharapkan dapat segera diminimalisir jumlah volume sampah yang ada di wisata Bangsring Underwater. Salah satunya dengan program berwisata bersih yang merupakan suatu program berwisata dengan tetap memperhatikan kebersihan lingkungan sekitar. Hal ini diwujudkan dengan gerakan berwisata dengan tidak meninggalkan sampah pada tempat wisata. Tempat wisata yang bersih dan bebas dari sampah akan menciptakan rasa nyaman bagi wisatawan ketika berwisata sehingga wisatawan akan betah dan tertarik untuk berkunjung kembali. Sesuai dengan hasil wawancara denga informan secara triangulasi bahwa program berwisata bersih sangatlah penting untuk diterapkan di Bangsring Underwater karena untuk menjadi solusi dalam permasalahan sampah yang semakin menumpuk dipermukaan laut Pantai Bangsring. Hal ini juga sesuai dengan konsep sapta pesona pariwisata yakni suatu destinasi wisata harus terdapat unsur kebersihan karena untuk memberikan kualitas produk dan pelayanan di dalam destinasi wisata. Selain itu bersih juga menunjukkan kondisi yang menampilkan suasana bebas dari sampah, limbah, kotoran, penyakit dan pencemaran. Dengan menjaga kebersihan tempat wisata akan menjadikan wisatawan merasa nyaman dan betah ketika berwisata.

Dalam program ini peneliti memanfaatkan totebag atau tas kain sebagai penyimpanan sampah yang efisien karena bebas dari plastik. Totebag merupakan tas standard klasik yang penggunaannya lebih nyaman untuk membawa semua jenis barang. Sebagian besar orang menggunakan tas jenis ini dalam kehidupan sehari-hari, yang menjadi pilihan tepat untuk tampil kasual bagi wanita maupun laki-laki. Namun totebag dalam program yang akan diterapkan yaitu mempunyai fungsi atau pemanfaatan sebagai tempat sampah yang dibawa oleh para wisatawan yg berkunjung. Totebag kain merupakan alternatif untuk mengurangi penggunaan limbah plastik. Selain itu totebag bersifat ramah lingkungan serta tidak mudah robek sehingga aman untuk menyimpan sampah plastik dan dapat digunakan berkelanjutan. Program berwisata bersih ini dilakukan dengan cara pemberian totebag ramah lingkungan kepada para wisatawan. Tujuan pemberian totebag ini agar wisatawan yang datang dapat menyimpan sampah wisatawan tersebut dan kemudian menyerahkan kepada pihak pengelola wisata.

Pada program ini pihak pengelola wisata akan memberikan arahan kepada wisatawan ketika wisatawan menerima totebag tersebut tentang fungsi dan kegunaannya. 
Sampah didalam totebag merupakan sampah yang diperoleh dari kemasan sisa makanan dan minuman yang dibawa oleh wisatawan saat berwisata dan sampah di sekitar mereka. Ketika wisatawan akan meninggalkan tempat wisata, untuk totebag yang berisi sampah dikembalikan kepada pihak pengelola dipintu keluar. Kemudian untuk wisatawan akan mendapatkan reward dari pihak pengelola wisata. Hal ini merupakan keunggulan dalam program yang dilakukan peneliti. Reward dalam program berwisata bersih yakni sebuah penghargaan untuk pengunjung wisata yang memiliki syarat dan mengikuti peraturan yang telah ditentukan oleh pihak pengelola wisata untuk ikut berperan dalam menanggulangi sampah di daerah wisata Bangsring Underwater. Dengan adanya reward maka wisatawan akan lebih tertarik untuk melaksanakan program ini. selain itu secara tidak langsung wisatawan akan timbul rasa kesadaran terdadap sampah sehingga wisatawan akan lebih peduli terhadap lingkungan sekitar pesisir pantai. Pengadaan reward ini merupakan program keunggulan karena dapat menarik wisatawan untuk mengurangi sampah dan untuk wisatawan tidak terbebani karena semakin banyak sampah yang wisatawan kumpulkan maka semakin besar reward yang akan didapatkan.

Hal ini didukung oleh pendapat dari informan A,B, dan D karena menurut informan kegiatan bersih pesisir pantai sudah sering diadakan di Pantai Bangsring, namun belum bisa terlaksana dengan baik. Kegiatan bersih Pantai Bangsring tersebut belum bisa menyadarkan kepedulian masyarakat atau wisatawan akan kebersihan lingkungan pesisir pantai. Selain itu kegiatan bersih pantai dengan pengadaan denda bagi yang membuang sampah tidak pada tempatnya juga pernah dilakukan di tempat wisata Bangsring Underwater Banyuwangi, namun juga belum bisa terlaksana dengan efektif dan juga belum bisa meningkatkan kesadaran dan kepedulian masyarakat pada lingkungan pesisir pantai. Program ini sangat cocok untuk diterapkan karena objek program ini ditujukan langsung kepada wisatawan. Dengan adanya reward, wisatawan akan lebih peduli karena wisatawan akan mendapat timbal balik dari pihak pengelola sehingga wisatawan tidak merasa dirugikan dengan mengumpulkan sampah kemasan sisa makanan dan minuman dan sampah di sekitar mereka. Wisatawan akan mendapatkan reward seperti gratis masuk tempat wisata, gratis tiket wanana dan fasilitas wisata (snorkling, rumah apung, bola air, kursi pantai, dan bananaboat) dan gratis tempat parkir. Dalam menentukan reward yang akan diperoleh wisatawan, pihak pengelola menentukan syarat untuk jenis dan banyaknya sampah yang dibawa didalam totebag. Selain itu reward memiliki keterkaitan terhadap ekonomi,sosial masyarakat dan ekologi. keterkaitan reward tersebut yaitu dengan pemberian reward terhadap wisatawan, Penerapan reward yang ditujukan kepada wisatawan adalah suatu penghargaan yang diberikan oleh pihak pengelola wisata kepada wisatawan yang memenuhi kualifikasi syarat dan mengikuti peraturan yang telah ditetapkan oleh pihak pengelola tentang kebersihan di tempat wisata. Pemberian reward hanya berlaku untuk satu orang dalam satu kelompok maupun individu. Untuk penggunaan reward yang diperoleh wisatawan dapat digunakan ketika wisatawan tersebut berkunjung kembali ke tempat wisata Bangsring Underwater Banyuwangi. Selain itu pemberian reward dalam program berwisata bersih ini akan menjadi daya tarik wisatawan untuk berkunjung dan akan meningkatkan kesadaran wisatawan dalam menjaga kebersihan tempat wisata sehingga akan berdampak baik bagi ekosistem yang ada di tempat wisata Bangsring Underwate Banyuwangi. Adapun kualifikasi untuk mendapatkan reward misalnya:

1. 10 Sampah botol plastik ukuran $1500 \mathrm{ml}$ reward bebas biaya salah satu tiket wahana.

2. 10 sampah botol plastik ukuran $600 \mathrm{ml}$ reward bebas biaya salah satu fasilitas wisata.

3. 10 Sampah campuran(kemasan makanan ringan,kantong plastik) reward bebas biaya parkir. 
Berdasarkan hasil pengumpulan sampah dari wisatawan, selanjutnya sampah akan disortir oleh pihak pengelola untuk didaur ulang. sampah yang dapat didaur ulang seperti botol plastik selanjutnya dijual kepada pengepul dan untuk hasilnya akan menjadi modal tambahan bagi pihak pengelola serta dapat dijadikan modal reward bagi wisatawan yang memenuhi syarat yang telah ditentukan. Selain itu, sampah campuran seperti kemasan sisa makanan ringan dan kantong plastik dapat dikelola menjadi kerajinan yang terbuat dari sampah dan hasil kerajinan dapat didistribusikan ditempat wisata tersebut untuk mendapatkan penghasilan tambahan bagi pihak pengelola untuk menambah modal bagi tempat wisata bahari yang menjalankan program ini. Seperti yang telah dijelaskan pada bab II tentang pengolahan limbah. Limbah yaitu sampah yang dapat didaur ulang adalah limbah anorganik seperti botol plastik, kaleng bekas, kain perca, pecahan kaca/keramik dan lain sebagainya. Daur ulang limbah jika dilakukan oleh orang-orang yang mempunyai kreativitas maka akan menghasilkan barang-barang baru yang berguna serta memiliki nilai estetika tinggi seperti daur ulang limbah menjadi kerajinan tangan dan dapat di pasarkan menjadi souvenir di tempat wisata Bangsring Underwater.

\section{Faktor pendorong dalam pelaksanaan program pengelolaan sampah dan limbah di tempat wisata Bangsring Underwater}

Faktor pendorong merupakan suatu hal sangat berpengaruh dalam mendorong atau menjadikan suatu program dapat berjalan dengan baik. Dalam penelitian ini, terdapat faktor-faktor yang akan mendorong berjalannya program ini dapat terlaksana, yakni pihak pengelola tempat wisata Bangsring Underwater Banyuwangi. Pihak pengelola merupakan pihak yang berkaitan langsung dalam mengelola pariwisata Bangsring Underwater Banyuwangi. Adanya dukungan dari pihak pengelola pariwisata dapat menjadikan program berwisata bersih berjalan dengan baik karena pihak pengelola memiliki peran penting dalam menjalankan program berwisata bersih. Pengelola wisata juga sebagai pengarah kepada wisatawan dalam penggunaan totebag. Pengelola wisata juga sebagai pengawas setiap aktivitas yang terjadi di tempat wisata. Menurut informan A dari aktivitas wisatawan selama ini wisatawan selalu meninggalkan kemasan sisa makanan dan minuman yang dibawa maupun yang dibeli di warung sekitar lokasi wisata. Adanya peran penting dari pihak pengelola wisata dalam menjalankan program wisata bersih serta dalam mengatasi wisatawan agar tidak lagi meninggalkan sampah di sekitar pantai. Selain itu pihak pengelola juga dapat menjadi pendorong dalam mempromosikan program berwisata bersih kepada wisatawan. Faktor pendorong yang kedua yaitu Dinas Pariwisata dan Dinas Lingkungan Hidup Banyuwangi yakni dapat mempromosikan program wisata bersih dengan menggunakan totebag untuk penyimpanan sampah yang mendapatkan reward maka akan meningkatkan minat pengunjung untuk berwisata kembali untuk menggunakan reward yang sebelumnya telah didapatkan. Dinas pariwisata dapat mensosialisasikan serta mempromosikan wisata Bangsring Underwater Banyuwangi kepada masyarakat tentang program berwisata bersih. Promosi yang dilakukan bisa melalui web dinas pariwisata sehingga dapat mempromosikannya kepada wisatawan luar kota atau mancanegara juga.

Selain itu, dinas lingkungan hidup juga berperan dalam mengkampanyekan serta mensosialisasikan program berwisata bersih kepada masyarakat sekitar. Dinas lingkungan hidup dapat mengkampanyekan manfaat program wisata bersih dalam hal menjaga lingkungan pesisir pantai. Hal ini yang menjadi tujuan utama dalam menjaga dan menanggulangi limbah sampah yang belebihan di daerah pesisir pantai sehingga wisata Bangsring Underwater Banyuwangi bebas limbah sampah dan menjadi pantai yang bersih. Dengan adanya kolaborasi dari pihak pengelola wisata Bangsring Underwater Banyuwangi, Dinas Pariwisata, dan juga Dinas Lingkungan Hidup dapat menjadi pendorong yang kuat dalam menanggulangi banyaknya limbah sampah di daerah pariwisata Bangsring Underwater Banyuwangi. Selain itu dari kolaborasi ketiga pihak dapat mewujudkan suatu wisata Bangsring Underwater Banyuwangi yang bersih dan 
menjadi destinasi wisata yang nyaman dan memberikan kepuasan untuk wisatawannya. Hal ini didukung oleh penelitian dari Chatlia, 2016 pada bab II yakni dengan adanya kolaborasi dari pihak Dinas Kebersihan dan Pertamanan dengan LSM dapat mewujudkan lingkungan wisata pantai yang bersih dan akan meningkatkan tingkat kesadaran atau kepedulian masyarakat dan wisatawan akan kebersihan lingkungan pesisir pantai.

\section{Faktor penghambat dalam pelaksanaan program pengelolaan sampah dan limbah di Pantai Bangsring}

Faktor penghambat dalam penelitian ini dapat diartikan sebagai tantangan yang harus dihadapi dalam pelaksanaan program wisata bersih. Tantangan yang dihadapi yakni dalam segi pengawasan. Melihat dari pengalaman sebelumnya, bahwa pihak pengelola wisata Bangsring Underwater Banyuwangi telah menerapkan regulasi patroli pantai khusus sampah yang ada di pesisir pantai daerah wisata tidak berjalan efektif disebabkan saat wisatawan meningkat pada musim liburan, tim patrol pantai yang seharusnya bertugas mengontrol sampah beralih fungsi sebagai tour guide. Hal ini menyebabkan pengawasan terhadap sampah menurun sehingga daerah wisata pesisir pantai menjadi kotor.

\section{Smpulan}

Program berwisata bersih dapat menjadi alternatif dalam menanggulangi atau mengurangi sampah di daerah wisata Bangsring Underwater Banyuwangi. Hal ini dapat menjadikan wisatawan lebih peduli dengan kebersihan lingkungan pesisir pantai. Program berwisata bersih juga dapat meningkatkan tingkat kesadaran wisatawan akan pedulinya tentang sampah dilingkungan pesisir pantai dan akan meningkatkan daya tarik wisatawan untuk berkunjung. Program ini bersifat reward (Penghargaan) sehingga wisatawan menjadi semangat dan tidak menjadi beban dalam mengumpulkan sampah. Hal ini yang membuat program berwisata bersih dapat dilakukan dengan efektif. Selain adapun Faktor pendukung dari program pariwisata bersih ini ialah dimana dari pihak pengelola wisata telah memberikan dukungan dalam pengembangan program ini selain itu, dukungan dari pihak-pihak yang terkait yakni dari Dinas Kebudayaan dan Pariwisata dan Dinas Lingkungan Hidup Kabupaten Banyuwangi yang dapat mendukung terjalannya program berwisata bersih di daerah wisata Bangsring Underwater Banyuwangi. Selain itu Faktor penghambat terealisasinya program berwisata bersih ini ialah masih kurangnya pengawasan dalam tempat wisata pantai karena kurangnya pengawas dapat mempengaruhi efektivitas berlangsungnya program berwisata bersih. Hal ini disebabkan kurangnya SDM yang sadar dan peduli akan kebersihan lingkungan. Namun faktor penghambat ini menjadi sebuah tantangan bangi pihak pengelola wisata.

\section{Saran}

Dalam berlangsungnya kegiatan berwisata bersih ini perlu disediakan SDM atau karyawan untuk mengawasi kefektifan wisatawan dalam menyimpan sampah pada totebag yang telah diberikan sehingga program wisata bersih dapat berjalan secara efektif. Selain itu untuk penelitian selanjutnya diharapkan untuk lebih menganalisis implementasi dalam pelaksanaan wisata bersih yang belum ada dalam penelitian ini.

\section{Daftar Pustaka}

BPS (Badan Pusat Statistik). 2019. https://www.bps.go.id/Diakses Tanggal17 April 2019: Pkl. 13.42

Bungin, Burhan. 2010. Metode Penelitian Kualitatif. Jakarta: Kencana.

Creswell, John W. 2015. Penelitian Kualitatif \& Desain Riset. Yogyakarta: Pustaka Pelajar. 
Hasan, M. Iqbal. 2006. Pokok-pokok Materi Metodologi Penelitian dan Aplikasinya. Jakarta: Ghalia Indonesia.

Indriantoro, Nur dan Bambang Supomo. 2002. Metodologi Penelitian Bisnis. Yogyakarta: BPFE-Yogyakarta.

Karmana, Oman. 2007.Cerdas Belajar Biologi, Grafindo Media Pratama, Bandung

Keputusan Menteri Perindustrian dan Perdagangan RI No. 231/MPP/KEP/7/1997 Pasal 1 tentang Limbah.

Larasati, Mega. 2017. https://foresteract.com/limbah-pengertian-jenis-dampak-danpengelolaan/. Diakses Tanggal 18 April 2019 : Pkl.14.00

Nazir. 2005. Metode Penelitian. Cetakan ke-6. Bogor Selatan: Ghalia Indonesia

Sugiyono, 2008. Metode Penelitian Kuantitatif, Kualitatif, R\&D. Bandung: Alfabeta

Spillane, James. 1982. Ekonomi Pariwisata. Yogyakarta: Kansius

Sutrisno, Edi. 2009. Manajemen Sumber Daya Manusia. Edisi pertama. Kencana Prenada Media Group. Jakarta.

Undang-undang Republik Indonesia No. 10 Tahun 2009 tentang Pariwisata.

www. mediaindonesia.com (diakses pada tanggal 30 November 2020, pkul: 14.14WIB)

www.suara.com/bisnis/2019/04/03/141249/kesedihan-susi-melihat-sampah-di-bangsringbanyuwangi-saat-beri-makan-ikan.( diakses pada tanggal 01 Desember 2020, pukul 10.03WIB) 
